\title{
Mast Cell Degranulation
}

National Cancer Institute

\section{Source}

National Cancer Institute. Mast Cell Degranulation. NCI Thesaurus. Code C114629.

The regulated exocytosis of secretory granules by a mast cell. 